\title{
The Biochemistry Over 20 Years In The High School Textbooks
}

Rocha, C. E. S. ${ }^{1}$; Büttenbender, M. D. ${ }^{1}$; Denardin, E.L.G. ${ }^{2}$, Roehrs, R. ${ }^{1,2}$

${ }^{1}$ Grupo Interdisciplinar de Pesquisa em Práticas de Ensino, UNIPAMPA, RS.

${ }^{2}$ Laboratório de Estudos Físico Químicos e Produtos Naturais, UNIPAMPA, RS.

INTRODUCTION: Many teachers make use of textbook to lead content in the classroom. The chemistry books introduce concepts that should relate biochemistry to students in schools. It is important that this first contact turns out into an encouraging experience for the students, because once it worked as expected it arouses interest and makes the students see themselves curious to delve into the subject. The research aims to evaluate the presence of related concepts in biochemistry textbooks in chemistry in high school, over 20 years. MATERIAL AND METHODS: In order to perform this study, we analyzed the following content related to biochemistry: proteins, carbohydrates, lipids and nucleic acids in the books "Chemistry - Structure of Matter and Organic Chemistry" of the year 1993 and the book "Chemistry in approach to daily life" of the year 2012 with the purpose of verifying the changes in the content of biochemistry in the last 20 years. RESULTS AND DISCUSSION: In the 90s, as used in the book, concepts and explanations are introduced in a very objective approach, making a total of 22 pages. The current largest is 23 pages with experiments and curiosities. Through analysis we found that current textbooks present the same issues related to biochemistry, however, a greater amount of data, bringing students to more examples and applications in everyday life. Today we see that the contents and processes are most exploited and that there is a concern on the importance of the study of issues that relate to biochemistry. CONCLUSIONS: The study of the biochemistry textbooks has been more attractive in recent years, contextualizing content with the daily life of students. This proves that biochemistry has gained importance in textbooks, and therefore in classroom.

Keywords: biochemistry, books, high school.

Sponsor: FAPESP, CNPq and CAPES. 